\title{
A FUZZY METHODOLOGY FOR LOCAL ENTREPRENEURIAL CULTURE EVALUATION: EVIDENCE FROM POST-SOVIET KYRGYZSTAN
}

\author{
A. Göleç ${ }^{1,2 *} \&$ A. Maksudunov ${ }^{3}$
}

\section{ARTICLE INFO}

\section{Article details}

Submitted by authors 1 Dec 2017

Accepted for publication 18 Apr 2019

Available online 29 May 2019

\section{Contact details}

* Corresponding author ademgolec@erciyes.edu.tr

Author affiliations

1 Department of Management, Faculty of Economics and Administrative Sciences, KyrgyzTurkish Manas University, Bishkek, Kyrgyzstan

2 Department of Industrial Engineering, Faculty of Engineering, Erciyes University, Kayseri, Turkey

3 Department of Management, Faculty of Economics and Administrative Sciences, KyrgyzTurkish Manas University, Bishkek, Kyrgyzstan

\section{ABSTRACT}

This paper assesses the local entrepreneurial culture based on the perceptions of local residents, by focusing on four distinct dimensions of the local entrepreneurial culture: 'diversity and change climate', 'business promotion climate', 'business discouragement climate', and 'focus on local'. A comprehensive survey was used to assess the local entrepreneurial culture in Bishkek, Kyrgyzstan. The items included in the survey were categorised as positive or negative statements that describe the respondent's county. This paper provides a framework that consists of a two-level model to construct a quantitative measure of local entrepreneurial culture. Essentially, a fuzzy artificial decision is based on data collected by conducting the survey with entrepreneurs and non-entrepreneurs. At the top level, a fuzzy multicriteria decision-making model was used to measure the local entrepreneurial culture. This model assesses the entrepreneurial culture in the community development practices of managers, contributes to future entrepreneurial research, identifies practices for entrepreneurial culture, and assesses the role of local cultural characteristics in entrepreneurship. This study includes a novel methodology, compared with those described in the literature, as it includes a conceptual model based on the perceptions of local residents. The results of this study showed that Bishkek's entrepreneurial culture is below the middle level.

\section{OPSOMMING}

'n Omvattende meningspeiling is gebruik die plaaslike entrepreneurskultuur in Bisjkek, Kirgisië te beoordeel. Dit word op grond van die persepsies van die plaaslike inwoners beoordeel deur vier dimensies van die plaaslike entrepreneurskultuur te ondersoek, naamlik diversiteit en veranderingsklimaat, besigheidbevorderingsklimaat, besigheid-ontmoedigingsklimaat en die fokus op plaaslike belange. Die items in die meningspeiling is gekategoriseer as positiewe of negatiewe stellings wat die respondent se distrik beskryf. Hierdie artikel verskaf ' $n$ raamwerk wat uit ' $n$ tweevlakkige model bestaan en gebruik kan word as ' $n$ kwantitatiewe maatstaf van plaaslike entrepreneurskultuur. ' $n$ Wasige, kunsmatige besluit is gegrond op die meningspeiling terugvoer. Op die boonste van die twee vlakke is ' $n$ wasige, multi kriteria besluitnemingsmodel gebruik om die plaaslike entrepreneurskapkultuur te meet. Die model assesseer die entrepreneurskultuur in die gemeenskapontwikkelingspraktyke van bestuurders, dit dra by tot toekomstige entrepreneurskapverwante navorsing en assesseer die rol van plaaslike kulturele eienskappe in entrepreneurskap. Hierdie studie sluit 'n nuwe metodologie in, teenoor dit wat in die literatuur beskryf is, omdat dit 'n konseptuele model gegrond op die plaaslike gemeenskap se persepsies insluit. Die resultate toon dat Bisjkek se entrepreneurskapkultuur ondergemiddeld is. 
Entrepreneurship is an important phenomenon in the market economy. It is also perceived as a main determinant of economic growth and social change. Entrepreneurial activities play a major role in both developed and developing countries. Several studies have revealed that the development of an entrepreneurial culture may differ, depending on the socio-cultural and economic environment of a country ([1] [2] [3] [4] [5] [6] [7]).

Over the last few years, promoting entrepreneurial activities and stimulating the emergence of entrepreneurs have been relevant issues for most countries. The development of entrepreneurship first requires the measurement and assessment of the entrepreneurial culture of the society in a country. 'Entrepreneurial culture' is conceptualised as a society that depicts the exhibits entrepreneurial attributes, values, mindsets, and behaviour [8]. In other words, an entrepreneurial culture is linked to the values shared by entrepreneurs, such as risk-taking, innovativeness, and proactiveness.

In countries where a centrally planned economic system has dominated for a long time, entrepreneurship activities cannot be expected to be common. Kyrgyzstan, which is a post-Soviet Union country that gained its independence in 1991, is no exception. However, after gaining independence, the spirit of entrepreneurship in Kyrgyzstan began to evolve and spread throughout the country. Transitioning from a planned economy to a market economy gives rise to particular difficulties, especially in the creation of an entrepreneurial culture. This is because, for a long time, all social and economic activities were controlled by the state, and citizens would have no incentive to take entrepreneurial risks.

Since gaining independence, several reforms to the market economy have been implemented in Kyrgyzstan, which have led to small and medium-sized enterprises emerging due to a change in mindset. According to the National Statistical Committee of the Kyrgyz Republic, 14,000 small and medium-sized enterprises currently operate in the country and have provided employment opportunities for about 88,300 people [9]. This drastic change has been recognised internationally and, according to the World Bank's Doing Business Report of 2016, the Kyrgyz Republic ranked 64 ${ }^{\text {th }}$ among 189 countries [10].

With the implementation of several reforms in the 25 years since gaining independence, there have been notable changes in the entrepreneurial culture of Kyrgyz citizens. However, limited empirical research has been done on the dimensions of this change related to entrepreneurial culture, and this study aims to fill this gap.

This paper begins with a review of the evaluation of entrepreneurial culture. Then the research methodology based on the specific research statements developed by Breazeale et al. [11] is presented. A two-level evaluation model was used to construct a quantitative measure of the local entrepreneurial culture. At the basic level, a fuzzy artificial decision was obtained, based on data collected by conducting the survey with entrepreneurs and non-entrepreneurs. At the top level, a fuzzy multicriteria decision-making model was used to measure the local entrepreneurial culture. The paper concludes by discussing the value and importance of this measurement for community development practices.

\section{LITERATURE REVIEW}

The issue of evaluating entrepreneurial culture has become of great interest in academic studies ([4] [12] [13] [8] [11]) and research reports published by international institutions ([14] [15] [16]). While some of these publications are based on the opinion of individuals, others are based at the organisational level. In other words, entrepreneurial culture and entrepreneurial activities are evaluated according to the opinions of non-entrepreneurial individuals, entrepreneurs, and experts alike.

Until the 1990s, a limited number of studies had been conducted on evaluating entrepreneurial activities and the indicators for comparative evaluation [17]. Subsequent studies have been carried out, with one of the most relevant being the global report of the Global Entrepreneurship Monitor 
(GEM). Initiated in 1999, this report covers the results from 62 economies completing the Adult Population Survey (APS) and 62 economies completing the National Expert Survey (NES). According to the report, 68 per cent of working-age adults, on average, perceive entrepreneurs in their societies as having a high status, and 42 per cent see good opportunities around them for starting a business [14]. Sweden was the highest-ranking country globally on this indicator (70.2\%). Kyrgyzstan has not yet been included in this ranking. Among the Central Asian countries, only Kazakhstan was included in this ranking, and its score in 2018 was 48.7 per cent for opportunity perceptions [18].

Another global study in this field is the Global Entrepreneurship Index (GEINDEX), developed by the Global Entrepreneurship and Development Institute. This index evaluates the entrepreneurial attitudes, abilities, and aspirations of 140 countries using a 14-dimensional scale. Kyrgyzstan ranked $92^{\text {nd }}$ among 137 countries in the GEINDEX ranking, with a rate of 21 per cent. Kyrgyzstan was also on the highest level on the human capital indicator and on the lowest level for risk-taking. Among the Central Asian countries, Kazakhstan came in $17^{\text {th }}$ with a rate of 30 per cent, and Tajikistan occupied the $95^{\text {th }}$ position with a rate of 20.7 per cent. The USA was the highest-ranking country $(89.4 \%)$ in the GEINDEX ranking [19].

The World Bank is one of the authorities that evaluates entrepreneurial activities. According to the World Bank Group Entrepreneurship Survey (WBGES), Kyrgyzstan came in $89^{\text {th }}$ with a rate of 1.08 among 138 countries. This report is based only on limited liability companies. Data is provided on new business entry density, defined as the number of newly registered corporations per 1000 working-age people [20].

The research of international institutions is important in evaluating entrepreneurial activities at national levels, and for international comparisons. However, such studies are criticised in the academic literature, as the conceptual foundations of most indices used in these studies are insufficiently developed [17]. Moreover, these indices mostly focus on national levels, overlooking the role of local cultural characteristics. Consequently, evaluating entrepreneurial culture at a local level is crucial for research [11]. As with many topics in this field, scholars have addressed this question in their studies. While some of these studies propose to adapt a scale for measuring entrepreneurial culture ([12] [11]), others aim to find the relationship between entrepreneurial activities and entrepreneurial culture ([1] [4] [13]). Table 1 summarises these other studies.

Recent literature has emphasised the significant relationship between culture and entrepreneurship. In these studies, entrepreneurial culture is considered to be of great importance for economic development. The evaluation of entrepreneurial culture is crucial for the implementation of plans, programmes, and strategies. The entrepreneurial activity of the Kyrgyz Republic is evaluated by some indices of international institutions. However, a limited number of studies are devoted to measuring local entrepreneurial culture. Entrepreneurial culture could play a major role in the economic success of Kyrgyzstan. Consequently, the evaluation of entrepreneurial culture is crucial to the promotion, policies, and practices of entrepreneurship.

In most of these studies, the data are collected by questionnaires or surveys that assess many domains on issues related to psychology, such as perceptions, opinions, emotional states, etc. The questionnaires have responses that are usually distributed using Likert scales, and require respondents to select one from a list of predetermined labels. However, fuzzy questionnaires have a structure that combines visual analogue and fuzzy linguistic scales when analysing responses. Fuzzy methods treat each data point individually, and therefore relevant information is not lost.

In the fuzzy studies, the problems encountered have been solved by fuzzy methods, which the researchers believe to be more effective than crisp studies. The strength of these fuzzy methods is described in detail by Haris and Rahman [22]. In this study, a fuzzy artificial decision is first obtained, based on data collected by the survey, and then a fuzzy multicriteria decision is employed to evaluate the local entrepreneurial culture. 
Table 1: A detailed summary of other studies

\begin{tabular}{|c|c|c|c|}
\hline Article & Nature of problem & Method & Advantage of method used \\
\hline [3] & $\begin{array}{l}\text { The nature and development of } \\
\text { entrepreneurship in Central Asian } \\
\text { countries in transition }\end{array}$ & $\begin{array}{l}\text { Interviews and } \\
\text { statistics }\end{array}$ & $\begin{array}{l}\text { It emphasises that historical, socio-cultural, and } \\
\text { economic contexts appear to be important } \\
\text { factors that affect the business environment }\end{array}$ \\
\hline [4] & $\begin{array}{l}\text { Investigating the role of culture by } \\
\text { identifying differences among the } \\
\text { USA, Korea, Fiji, India, and Malaysia }\end{array}$ & $\begin{array}{l}\text { Survey and } \\
\text { analytical } \\
\text { research }\end{array}$ & $\begin{array}{l}\text { It suggests that the highest level of } \\
\text { entrepreneurial activity does not show the } \\
\text { highest level of entrepreneurial orientation }\end{array}$ \\
\hline [7] & $\begin{array}{l}\text { An empirical comparative research } \\
\text { study among entrepreneurs from } \\
\text { Romania and Moldova }\end{array}$ & $\begin{array}{l}\text { Survey and } \\
\text { analytical } \\
\text { research }\end{array}$ & $\begin{array}{l}\text { The results of the study present particular } \\
\text { similarities and differences between both } \\
\text { countries }\end{array}$ \\
\hline [8] & $\begin{array}{l}\text { The relationship between } \\
\text { entrepreneurship awareness and } \\
\text { entrepreneurial culture }\end{array}$ & $\begin{array}{l}\text { Survey and } \\
\text { analytical } \\
\text { research }\end{array}$ & $\begin{array}{l}\text { It emphasises that the entrepreneurship } \\
\text { awareness promotion programmes were a crucial } \\
\text { factor in the development of entrepreneurial } \\
\text { culture }\end{array}$ \\
\hline [11] & $\begin{array}{l}\text { Measuring the local entrepreneurial } \\
\text { culture }\end{array}$ & $\begin{array}{l}\text { Survey and } \\
\text { analytical } \\
\text { research }\end{array}$ & $\begin{array}{l}\text { It evaluates an entrepreneurial culture at a local } \\
\text { level }\end{array}$ \\
\hline [12] & $\begin{array}{l}\text { Measuring the international } \\
\text { entrepreneurial culture }\end{array}$ & $\begin{array}{l}\text { Survey and } \\
\text { analytical } \\
\text { research }\end{array}$ & $\begin{array}{l}\text { It proposes a comprehensive opportunity-based } \\
\text { operationalisation of international } \\
\text { entrepreneurship }\end{array}$ \\
\hline [13] & $\begin{array}{l}\text { Investigating the family } \\
\text { entrepreneurship culture, } \\
\text { entrepreneurial intent, and futures } \\
\text { foresight }\end{array}$ & $\begin{array}{l}\text { Analytical } \\
\text { research }\end{array}$ & $\begin{array}{l}\text { It develops foresight by considering both the } \\
\text { community and business aspects as part of a } \\
\text { coherent whole }\end{array}$ \\
\hline [18] & $\begin{array}{l}\text { The importance of education in the } \\
\text { development of entrepreneurial } \\
\text { culture }\end{array}$ & $\begin{array}{l}\text { Survey and } \\
\text { analytical } \\
\text { research }\end{array}$ & $\begin{array}{l}\text { It emphasises the importance of promoting } \\
\text { entrepreneurial values in people with secondary } \\
\text { education level }\end{array}$ \\
\hline [19] & $\begin{array}{l}\text { The special programme's impact on } \\
\text { increasing entrepreneurship culture } \\
\text { among students }\end{array}$ & $\begin{array}{l}\text { Survey and } \\
\text { analytical } \\
\text { research }\end{array}$ & $\begin{array}{l}\text { It discovers that the entrepreneurial skills and } \\
\text { interests of students are enhanced at the end of } \\
\text { the programme }\end{array}$ \\
\hline [20] & $\begin{array}{l}\text { Investigating entrepreneurial culture } \\
\text { by using participative observation } \\
\text { methodology }\end{array}$ & $\begin{array}{l}\text { Participative } \\
\text { observation } \\
\text { methodology }\end{array}$ & $\begin{array}{l}\text { It reveals that the influence of Arab culture on } \\
\text { the enterprise creation process is significant }\end{array}$ \\
\hline [21] & Entrepreneurial culture in Singapore & $\begin{array}{l}\text { Analytical } \\
\text { research }\end{array}$ & $\begin{array}{l}\text { It emphasises the importance of promoting the } \\
\text { entrepreneurial culture of citizens }\end{array}$ \\
\hline [22] & $\begin{array}{l}\text { Detecting the fuzzy methods used in } \\
\text { entrepreneurship domains }\end{array}$ & $\begin{array}{l}\text { Analytical } \\
\text { research }\end{array}$ & $\begin{array}{l}\text { It acquires meaningful knowledge in various } \\
\text { areas of entrepreneurship domains }\end{array}$ \\
\hline [23] & $\begin{array}{l}\text { Detecting a versatile criterion set for } \\
\text { evaluating entrepreneurial universities }\end{array}$ & $\begin{array}{l}\text { The fuzzy AHP } \\
\text { and fuzzy TOPSIS }\end{array}$ & $\begin{array}{l}\text { The results can be used in higher education } \\
\text { institutions and universities to create new } \\
\text { businesses }\end{array}$ \\
\hline [24] & $\begin{array}{l}\text { An evaluation model for an } \\
\text { entrepreneurial environment }\end{array}$ & $\begin{array}{l}\text { Fuzzy sets and } \\
\text { fuzzy AHP }\end{array}$ & $\begin{array}{l}\text { The model can be used as an accurate, effective, } \\
\text { and systematic decision-support tool }\end{array}$ \\
\hline [25] & $\begin{array}{l}\text { Detecting the personality traits and } \\
\text { emotional intelligence factors that } \\
\text { affect entrepreneurial intention }\end{array}$ & Fuzzy DEMATEL & $\begin{array}{l}\text { It determines the need for achievement as the } \\
\text { most significant factor that affects } \\
\text { entrepreneurial intention }\end{array}$ \\
\hline [26] & $\begin{array}{l}\text { Developing the soft-computing-based } \\
\text { key entrepreneurial competencies } \\
\text { model }\end{array}$ & Neuro-fuzzy & $\begin{array}{l}\text { The model can predict or evaluate the quality of } \\
\text { the obtained entrepreneurial competencies from } \\
\text { various entrepreneurship training programmes }\end{array}$ \\
\hline [27] & $\begin{array}{l}\text { Developing the economic- } \\
\text { psychological model of factors that } \\
\text { influence the intentions of individuals } \\
\text { going into business }\end{array}$ & Fuzzy logic & $\begin{array}{l}\text { The model suggests that entrepreneurial } \\
\text { intention is related to a composite of various } \\
\text { demographics, competencies, networks, and } \\
\text { perception factors }\end{array}$ \\
\hline [28] & $\begin{array}{l}\text { Making the primary screening of a } \\
\text { business opportunity affected by } \\
\text { several factors }\end{array}$ & Fuzzy AHP & $\begin{array}{l}\text { The model can be useful for entrepreneurial } \\
\text { service experts who have knowledge about } \\
\text { factors related to an opportunity }\end{array}$ \\
\hline [29] & $\begin{array}{l}\text { Determining the necessary and } \\
\text { sufficient conditions for higher } \\
\text { entrepreneurial rates }\end{array}$ & $\begin{array}{l}\text { Fuzzy qualitative } \\
\text { analysis }\end{array}$ & $\begin{array}{l}\text { The fuzzy analysis identifies that media } \\
\text { attention to entrepreneurship, perceived } \\
\text { capabilities, and perceived opportunities are the } \\
\text { most relevant conditions }\end{array}$ \\
\hline [30] & $\begin{array}{l}\text { Categorising the entrepreneurial } \\
\text { barriers in the industry of Iran }\end{array}$ & Fuzzy DEMATEL & $\begin{array}{l}\text { The model demonstrates that the most } \\
\text { important factors are the kind of management } \\
\text { and organisational structure }\end{array}$ \\
\hline [31] & $\begin{array}{l}\text { The local institutional complexity of } \\
\text { social entrepreneurship }\end{array}$ & Fuzzy sets & $\begin{array}{l}\text { The results show that local authorities are a } \\
\text { dominant condition, and local institutions need } \\
\text { to be in place to encourage the advancement of } \\
\text { social entrepreneurship }\end{array}$ \\
\hline [32] & $\begin{array}{l}\text { An approach to measuring } \\
\text { entrepreneurship orientation }\end{array}$ & Fuzzy AHP & $\begin{array}{l}\text { The approach categorises the firms based on } \\
\text { entrepreneurship orientation scores }\end{array}$ \\
\hline
\end{tabular}

\section{RESEARCH METHODOLOGY}

In this study, a scale developed by Breazeale et al. [11] was used. The scale measures local entrepreneurial culture based on the perceptions of residents. Factor analysis was used to identify 
the underlying attributes of local entrepreneurial culture. The four major factors determined were: 'diversity and change', 'business promotion', 'business discouragement', and a community-wide 'focus on local'. The validity of the scale was tested by associating the questionnaire results with the local rates of self-employment, controlling for important individual-level factors, and whether 'local' is rural or urban. The analysis results showed that the scale can measure entrepreneurial activity and can be a tool for evaluating entrepreneurial culture in other contexts.

Probability theory is associated with well-defined events and not with facts. It predicts the chance of whether or not those events will occur. On the other hand, fuzzy set theory tries to capture the essential concept of vagueness and defines the degree to which an event belongs to a set. In other words, probability theory deals with the frequency of occurrence in crisp events, whereas fuzzy set theory is associated with the degree of occurrence in crisp events ([33]).

In this study, the theory of fuzzy sets that captures the meaning of partial truth was used, instead of the probability theory that captures partial knowledge. In current studies using the Likert rating scale, probability theory is used, based on the frequency of different answers given to a statement (event); and the evaluation is also based on this approach. This study uses fuzzy set theory, based on the truth value obtained from the frequency of different answers given to a statement. Thus the methodology used is based on the value of the truth (possibility) of a statement.

Data was collected by using a questionnaire developed by Breazeale et al. [11], to measure local entrepreneurial culture. The entrepreneurial culture measurement questionnaire (ECMQ) consisted of 36 items. The questions were arranged as a five-point Likert-type scale, where $1=$ strongly disagree and $5=$ strongly agree. The original questionnaire was professionally translated into the Kyrgyz language by a bilingual person. The questionnaire forms were subjected to a sample of respondents in a pilot study. Omissions and questions that could cause misunderstanding were corrected. The corrected survey was then implemented among 400 respondents in Bishkek, the capital of Kyrgyzstan. The surveys were conducted using the face-to-face questionnaire method between July and September 2016. After the data was collected, it was appropriately encoded and analysed.

A reliability analysis was conducted for the factors that were used. Cronbach's alpha is one of the most widely used reliability statistics [34]. It measures the internal consistency of multi-point formatted questionnaires or scales (i.e., rating scale: 1 = strongly disagree, $5=$ strongly agree). The alpha coefficient ranges in value from 0 to 1 . The higher the score, the more reliable the generated scale is. George and Mallery provided the following rules of thumb: $>>.9$ - Excellent, $>>.8$ - Good, ${ }_{-}>.7$ - Acceptable, _> .6 - Questionable, _> .5 - Poor, and _<.5 - Unacceptable [35]. In this study, diversity and change, business promotion, business discouragement, and focus on local factors were rated on Cronbach's alpha as 0.722 (acceptable), 0.567 (poor), 0.552 (poor), and 0.663 (questionable) respectively. Cronbach's alpha was 0.863 for all 36 items and indicated good internal consistency for the 36 items in the scale.

\section{THE MODEL TO EVALUATE LOCAL ENTREPRENEURIAL CULTURE}

A two-level model was used to construct a quantitative measure of the local entrepreneurial culture. At the basic level, based on data collected by conducting the survey with entrepreneurs and nonentrepreneurs in Bishkek, a fuzzy artificial decision was obtained to use as the input for the top level. At the top level, a fuzzy multicriteria decision was used to determine the local entrepreneurial culture.

\subsection{Basic level}

The factors of diversity and change, focus on local, business promotion, and business discouragement shown in Figure 3 were used as the basic factors for a fuzzy artificial decision. The factors and their sub-components are:

$$
\begin{gathered}
F_{i}=\left\{f_{i}^{n_{i}}\right\}, \quad i=1,2, \ldots, I . \quad I=4 \text { (factor numbers), } \\
\left.n_{i}=1,2, \ldots, N_{i}, N_{1}=10, N_{2}=7, N_{3}=10, N_{4}=9 \text { (\# of sub-components). } \quad \text { (Equation } 1\right)
\end{gathered}
$$

The rating scale set to evaluate the entrepreneurial community culture, based on resident perceptions, is: 


$$
P=\left\{p_{l}\right\}, l=1,2, \ldots, L .
$$

(Equation 2)

Residents have five different view options $(L=5)$ about their county, and how supportive it is of local entrepreneurship.

Let $U$ be the space of local entrepreneurial culture,

$$
U=\left\{u_{m}\right\}, m=1 .
$$

A singular factor evaluation for $u_{m}, \tilde{f}: F_{i} \rightarrow P$, from $F_{i}$ to $P$, is a fuzzy mapping, and fuzzy mapping $\tilde{f}$,

$$
T_{i m} \in \mathrm{M}_{N_{i} \times L}
$$

is a fuzzy relation, and is represented by a fuzzy matrix. It is normalised original data of the singular factor evaluation for $u_{m}$ and transformed to $T_{i m}$ matrix.

The weights associated with the factor sub-component,

$$
W_{i} \in \mathrm{M}_{1 \times N_{i}}
$$

are a fuzzy subset in $F_{i}$, and are represented by a fuzzy vector. The fuzzy AHP extended by Göleç and Tașkın was used to determine the weights associated with the factor sub-component [36].

Let $T_{i m}$ be input, $T: F_{i} \rightarrow P$, from $F_{i}$ to $P$, is computed with a fuzzy transformation.

So the artificial decision statement is defined as:

$$
B_{i m}=W_{i}^{\circ} T_{i m}
$$

where $B_{i m}$ is a fuzzy relation; and then the following operation is applied for the membership values:

$$
\mu_{W_{i}{ }^{\circ} T_{i m}}(p) \triangleq \sum_{f_{i} \in F_{i}} \mu_{W_{i}}\left(f_{i}\right) \cdot \mu_{T_{i m}}\left(f_{i}, p\right)
$$

where $\mu_{W_{i}}\left(f_{i}\right), \mu_{T_{i m}}\left(f_{i}, p\right)$, and $\mu_{W_{i} \circ T_{i m}}(p)$ are the membership functions of $W_{i}, T_{i m}$, and $W_{i}{ }^{\circ} T_{i m}$ respectively. $B_{i m}$ is a fuzzy subset and a fuzzy vector in $P$ and can also be represented by $B_{i m} \in \mathrm{M}_{1 \times L}$.

The rating scale weights of how strongly the respondents agree or disagree with the statements about the county are represented by $W_{c} \in \mathrm{M}_{1 \times L}$. For the rating scale weights, rank weights are obtained by the following equation:

$$
w_{j}=\frac{r_{j}}{\sum_{k=1}^{n}\left(n-r_{k}+1\right)}
$$

$n$ rating scales were ranked from strongly disagree to strongly agree, and each scale was weighted with $r_{j}$ where $r_{j}$ is the rank position of the scale. Each weight was normalised by $\sum_{k=1}^{n}\left(n-r_{k}+1\right)$ [37].

A fuzzy transformation for $r_{i m}$ can be written as

$$
r_{i m}=B_{i m}{ }^{\circ} W_{c}^{T}
$$

where

$$
\mu_{B_{i m}{ }^{\circ} W_{c}^{T}}\left(F_{i}\right) \triangleq \sum_{p \epsilon P} \mu_{B_{i m}}(p) \cdot \mu_{W_{c}^{T}}\left(p, F_{i}\right)
$$

$r_{i m}$ can be shown in Figure 1. The $r_{i m}$ values of the artificial decision were used as the input for the top level. 


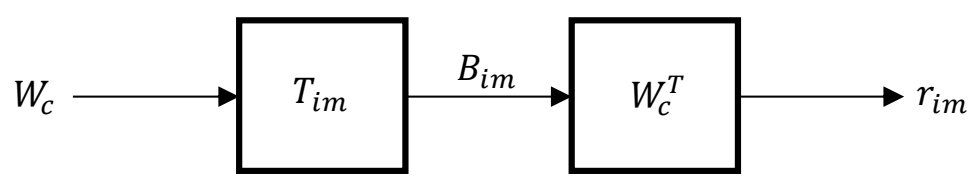

Figure 1: Illustration of $r_{i m}$

\subsection{Top level}

The factor sets of the top level are based on the basic level and a multicriteria decision set, which consists of the following:

Let $F$ be the factor sets:

$$
F=\left\{F_{i}\right\}
$$

Decision criteria set $C$ consists of $J$ decision criteria based on the factors below.

$$
C=\left\{c_{j}\right\}, \quad j=1,2, \ldots, J, J=5 .
$$

The following decision criteria can be created to calculate a quantitative measure of local entrepreneurial culture.

$c_{1}$ : If the residents are more optimistic about the local culture's openness to diversity and change, it seems that local entrepreneurship rates are good in counties.

$c_{2}$ : If the residents are more optimistic about the local culture's openness to diversity and change, and the business promotion climate is sustainable, it seems that local entrepreneurship rates are very good in counties.

$c_{3}$ : If the residents are more optimistic about the local culture's openness to diversity and change, the business promotion climate is sustainable, and there is a community-wide focus on local, it seems that local entrepreneurship rates are excellent in counties.

$c_{4}$ : If the residents are more optimistic about the local culture's openness to diversity and change, the business promotion climate is sustainable, there is a community-wide focus on local, and there is no climate of business discouragement, it seems that local entrepreneurship rates are exceptional in counties.

$c_{5}$ : If the residents are more pessimistic about the local culture's openness to diversity and change, and the business promotion climate is not sustainable, it seems that local entrepreneurship rates are poor in counties.

The evaluation sets can be defined as follows:

$$
A=\left\{A_{k}\right\}, \quad k=1,2, \ldots, K, \quad K=5,
$$

and the evaluation functions $A(v)$ can be defined as follows:

$$
\begin{aligned}
& A_{1}=\text { Good: } \\
& A_{2}=\text { Very good: } \\
& A_{3}=\text { Excellent: } \\
& A_{4}=\text { Exceptional: } \\
& A_{5}=\text { Poor: } \\
& A_{1}(v)=v \text {, } \\
& A_{2}(v)=v^{3 / 2} \text {, } \\
& A_{3}(v)=v^{2} \text {, } \\
& A_{4}(v)= \begin{cases}1, & v=1, \\
0, & v \neq 1,\end{cases} \\
& A_{5}(v)=1-v \text {, }
\end{aligned}
$$

Where

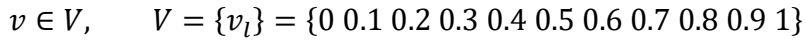

$$
\begin{aligned}
& l=1,2, \ldots, L, \quad L=11 \text {. }
\end{aligned}
$$

is the unit evaluation space (Figure 2). 


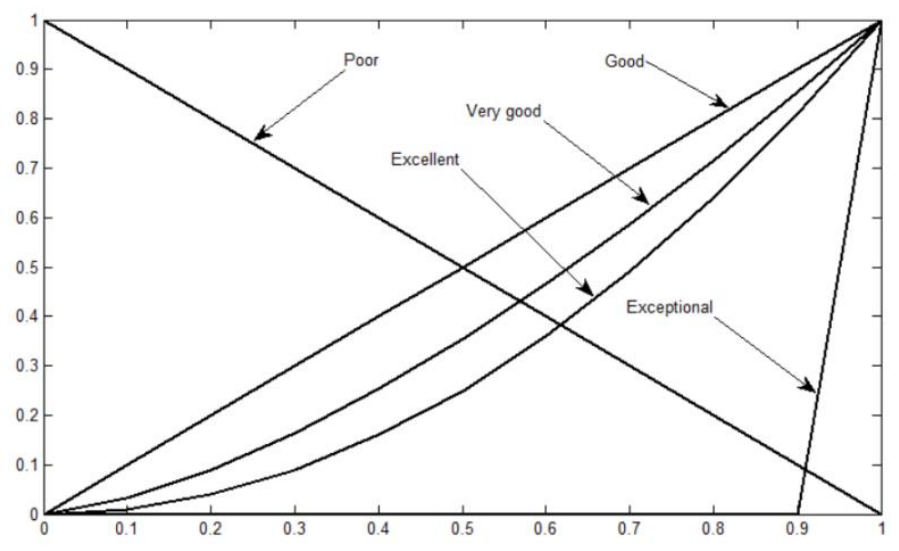

Figure 2: The unit evaluation space, $v$.

The five criteria above can be stated as follows:

$\begin{array}{lll}\text { If } \quad c_{1}=F_{1}, & \text { then } & A_{1} \\ \text { If } \quad c_{2}=F_{1} \cap F_{2}, & \text { then } & A_{2} \\ \text { If } \quad c_{3}=F_{1} \cap F_{2} \cap F_{3}, & \text { then } & A_{3} \\ \text { If } \quad c_{4}=F_{1} \cap F_{2} \cap F_{3} \cap F_{4}, & \text { then } & A_{4} \\ \text { If } \quad c_{5}=F_{1}, & \text { then } & A_{5}\end{array}$

A single-factor evaluation for a quantitative measure of local entrepreneurial culture at the top level was a fuzzy mapping from $F$ to $U, \tilde{f}: F \rightarrow U$, and a fuzzy matrix was represented by:

$$
R=\left(R_{i m}\right) \in \mathrm{M}_{l \times M}
$$

(Equation 16)

$R$ can be used as the input for the top level. When processed according to the decision criteria, a fuzzy matrix can be obtained from a fuzzy mapping, $\tilde{f}: C \rightarrow U$, and a fuzzy inference of probability can be used as follows:

$$
\begin{aligned}
& \text { If } x=\tilde{c}_{1}, \quad \text { then } y=A_{1} \\
& \text { If } x=\tilde{c}_{2}, \quad \text { then } y=A_{2} \\
& \text { If } x=\tilde{c}_{3}, \quad \text { then } y=A_{3} \\
& \text { If } x=\tilde{c}_{4}, \quad \text { then } y=A_{4} \\
& \text { If } x=\tilde{c}_{5}, \quad \text { then } y=A_{5}
\end{aligned}
$$

From the above inference system, the following matrix can be obtained:

$$
D_{j}=\left(d_{j}(m, l)\right) \in \mathrm{M}_{M \times L}
$$

(Equation 17)

where $d_{j}(m, l)=1 \wedge\left(1-\tilde{c}_{j}\left(u_{m}\right)+A_{k}\left(v_{l}\right)\right)$ is a fuzzy mapping from $U$ to $V, \tilde{f}: U \rightarrow V$. Then, a fuzzy multicriteria decision matrix,

$$
D=\bigcap_{j=1}^{J} D_{j} \triangleq\left(\prod_{j=1}^{J} d_{j}(m, l)\right)=\left(\tilde{E}_{m}\right) \in \mathrm{M}_{1 \times L}
$$

is obtained. Thus, $D$ is a fuzzy mapping from $U$ to $V, \tilde{f}: U \rightarrow V$, and $\tilde{E}_{m}$ is a fuzzy subset of unit evaluation space $V$ representing the degrees of good for local entrepreneurial culture, $u_{1}$.

Let $E_{m \alpha}$ be a-cut sets, $\alpha \in[0,1]=I$, of $\tilde{E}_{m} . E_{m \alpha}$ sets are the ordered subsets of $V$. The average values of elements in $E_{m \alpha}$ can be calculated by the following formula:

$$
H_{l}\left(E_{m \alpha}\right)=\frac{1}{N_{\alpha}} \sum_{n=1}^{N_{\alpha}} Z_{n}(\alpha)
$$


where $\alpha$ is the level of level-set and $Z_{n}(\alpha), Z_{n}(\alpha) \in E_{m \alpha}$ are the elements in $E_{m \alpha} . N_{\alpha}$ is the number of sequence of the finite sets of $E_{m \alpha}$. Then the point value of $\tilde{E}_{m}$ can be calculated by the following formula [38]:

$$
S(m)=\frac{1}{\alpha_{\max }} \sum_{l=1}^{L} H_{l}\left(E_{m \alpha}\right) \Delta \alpha_{l},
$$

where $\alpha_{\text {max }}$ is the maximum membership value of $\tilde{E}_{m}$ and

$$
\Delta \alpha_{l}=\alpha_{l}-\alpha_{l-1}, \alpha_{1}=0 .
$$

$S(m)$ is the value that measures the local entrepreneurial culture.

\section{APPLICATION}

Data was collected for a quantitative measurement methodology of local entrepreneurial culture based on the perceptions of entrepreneurs and non-entrepreneurs resident in Bishkek, Kyrgyzstan. The survey data is an entirely independent data set that estimated county-level rates of entrepreneurship, since one aim of the research was to use a scale that could be calculated for county-level entrepreneurship.

A total of 36 items, clustered as diversity and change, focus on local, business promotion, and business discouragement are adapted from measured attitude in this survey [11]. A framework to evaluate local entrepreneurial culture is constructed in Figure 3 [11].

The model constructed in Section 4 was applied, based on the framework in Figure 3. The factors in Level 2 of Figure 3 are the basic factors $\left(F_{i}\right)$ for a fuzzy artificial decision. The indicators in Level 3 are the sub-components $\left(f_{i}^{n_{i}}\right)$ of the factors in Level 2, and measure 'attitude' in this survey. In Level 4, using the rating scale below, residents can tell how strongly they agree or disagree with each of the local entrepreneurship statements about the county:

$P=\{1,2,3,4,5\}=\{$ strongly disagree, disagree, neutral, agree, strongly agree $\}$.

The fuzzy relation matrices $\left(T_{i m}\right)$ normalised the original data of the singular factor evaluation for $u_{m}$, and are given in Table 2 .

The weights $\left(W_{i}\right)$ associated with the factor sub-component are given in Table 3 . The artificial decision statement $\left(B_{i m}\right)$ is given in Table 4.

\begin{tabular}{|c|c|c|c|c|c|c|c|c|c|c|c|}
\hline \multirow{9}{*}{$T_{11}=$} & 0.1071 & 0.1735 & 0.3010 & 0.2781 & 0.1403 & \multirow{9}{*}{$T_{21}=$} & \multirow{2}{*}{$\begin{array}{l}0.1190 \\
0.1285\end{array}$} & \multirow{2}{*}{$\begin{array}{l}0.1190 \\
0.2368\end{array}$} & \multirow{2}{*}{$\begin{array}{l}0.2076 \\
0.3023\end{array}$} & \multirow{2}{*}{$\begin{array}{l}0.3215 \\
0.2519\end{array}$} & \multirow{2}{*}{$\begin{array}{l}0.2329 \\
0.0806\end{array}$} \\
\hline & 0.1159 & 0.2494 & 0.2997 & 0.2469 & 0.0882 & & & & & & \\
\hline & 0.1554 & 0.2632 & 0.2732 & 0.2180 & 0.0902 & & \multirow{2}{*}{$\begin{array}{l}0.1718 \\
0.1190\end{array}$} & 0.2667 & 0.3000 & 0.2077 & 0.0538 \\
\hline & $\begin{array}{l}0.1954 \\
0.1462\end{array}$ & $\begin{array}{l}0.3059 \\
0.2282\end{array}$ & $\begin{array}{l}0.2751 \\
0.2667\end{array}$ & $\begin{array}{l}0.1671 \\
0.2590\end{array}$ & $\begin{array}{l}0.0566 \\
0.1000\end{array}$ & & & \multirow{2}{*}{$\begin{array}{l}0.1873 \\
0.3030\end{array}$} & \multirow{2}{*}{$\begin{array}{l}0.1722 \\
0.3384\end{array}$} & 0.3241 & 0.1975 \\
\hline & $\begin{array}{l}0.1462 \\
0.1247\end{array}$ & $\begin{array}{l}0.2282 \\
0.2188\end{array}$ & $\begin{array}{l}0.2667 \\
0.3053\end{array}$ & $\begin{array}{l}0.2590 \\
0.2646\end{array}$ & $\begin{array}{l}0.1000 \\
0.0865\end{array}$ & & 0.1212 & & & 0.1818 & 0.0556 \\
\hline & 0.1148 & 0.2959 & 0.3061 & 0.2168 & 0.0663 & & \multirow{2}{*}{$\begin{array}{l}0.1190 \\
0.1320\end{array}$} & \multirow{2}{*}{$\begin{array}{l}0.2977 \\
0.2741\end{array}$} & \multirow{2}{*}{$\begin{array}{l}0.3410 \\
0.3198\end{array}$} & 0.1985 & 0.0433 \\
\hline & 0.1371 & 0.2157 & 0.2766 & 0.2792 & 0.0914 & & & & & 0.2208 & 0.0533 \\
\hline & 0.0863 & 0.2208 & 0.3299 & 0.2741 & 0.0888 & & & & & & \\
\hline & ${ }^{0.1231}$ & 0.2789 & 0.2789 & 0.2337 & 0.0854 & & & & & & \\
\hline & 0.2839 & 0.1080 & 0.1960 & 0.2814 & 0.1307 & & 0.1349 & 0.2366 & 0.3511 & 0.2188 & 0.0585 \\
\hline & 0.1713 & 0.3149 & 0.2846 & 0.1940 & 0.0353 & & 0.1367 & 0.1646 & 0.3089 & 0.3063 & 0.0835 \\
\hline & 0.0964 & 0.2081 & 0.3299 & 0.2690 & 0.0964 & & 0.1308 & 0.2333 & 0.2718 & 0.2821 & 0.0821 \\
\hline & 0.1696 & 0.2962 & 0.2506 & 0.2177 & 0.0658 & & 0.1291 & 0.2911 & 0.2633 & 0.2278 & 0.0886 \\
\hline & 0.1462 & 0.2436 & 0.2821 & 0.2462 & 0.0821 & $T_{41}=$ & 0.1212 & 0.2197 & 0.3283 & 0.2273 & 0.1035 \\
\hline 1 & 0.1574 & 0.2234 & 0.1827 & 0.3223 & 0.1142 & & 0.1544 & 0.3114 & 0.2380 & 0.2051 & 0.0911 \\
\hline & 0.1080 & 0.2412 & 0.3467 & 0.2286 & 0.0754 & & 0.1575 & 0.3250 & 0.2200 & 0.2150 & 0.0825 \\
\hline & 0.0787 & 0.1853 & 0.3959 & 0.2716 & 0.0685 & & 0.1218 & 0.3401 & 0.2817 & 0.1929 & 0.0635 \\
\hline & 0.0882 & 0.2191 & 0.3778 & 0.2343 & 0.0806 & & 0.1641 & 0.2753 & 0.2803 & 0.2298 & 0.0505 \\
\hline & 0.0856 & 0.1411 & 0.2872 & 0.2997 & 0.1864 & & & & & & \\
\hline
\end{tabular}

Table 2: The fuzzy relation matrices $\left(\boldsymbol{T}_{i m}\right)$ used as input 


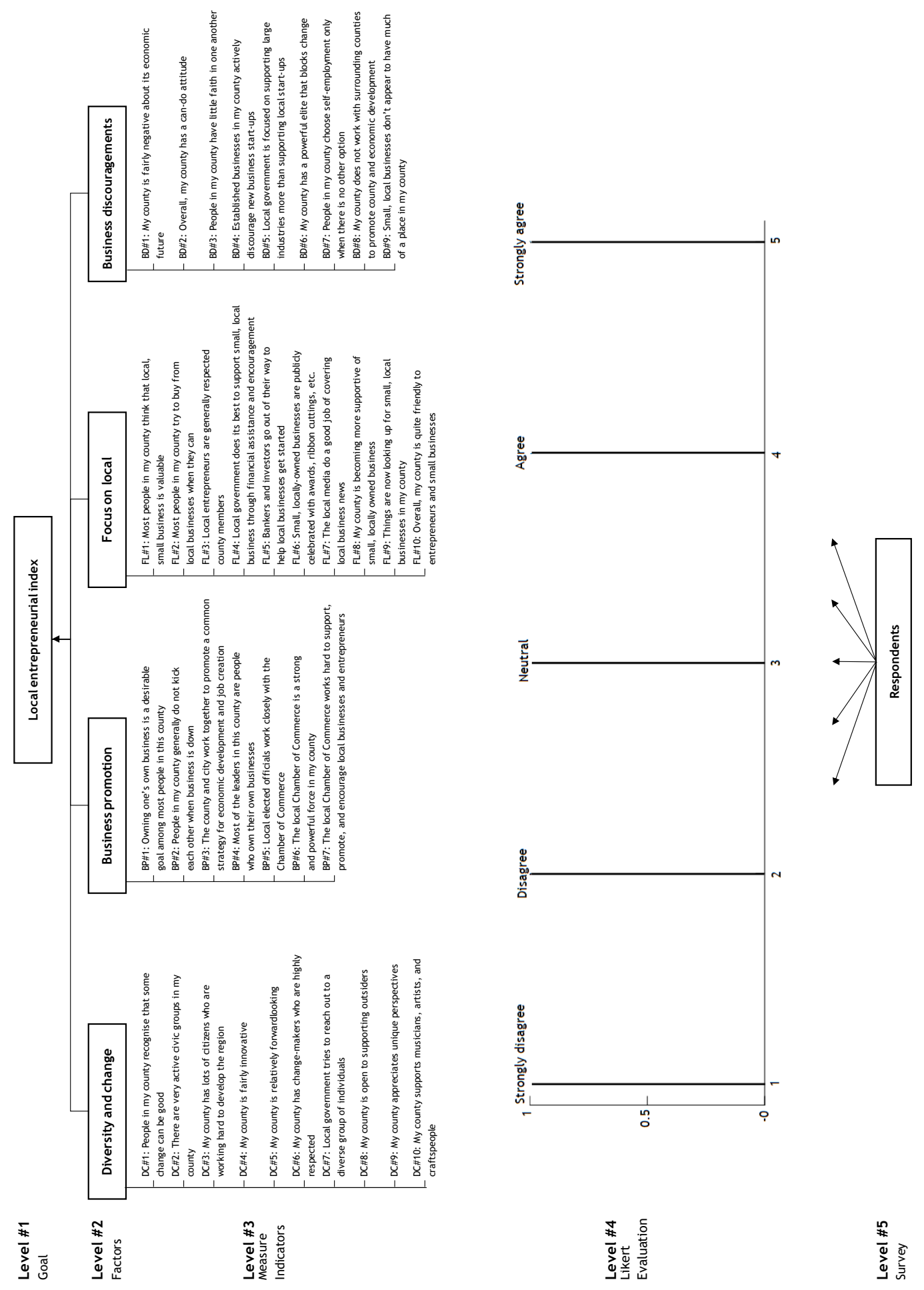

Figure 3: The hierarchy to determine the local entrepreneurial culture 


$$
\begin{aligned}
& W_{1}=\left[\begin{array}{llllllllll}
0.1314 & 0.1487 & 0.1268 & 0.1210 & 0.1119 & 0.0876 & 0.0712 & 0.0798 & 0.0697 & 0.0519
\end{array}\right] \\
& W_{2}=\left[\begin{array}{lllllll}
0.2565 & 0.1152 & 0.1867 & 0.1179 & 0.1247 & 0.1080 & 0.0909
\end{array}\right] \\
& W_{3}=\left[\begin{array}{llllllllll}
0.1495 & 0.1437 & 0.0979 & 0.1246 & 0.1119 & 0.0661 & 0.0790 & 0.0811 & 0.0759 & 0.0703
\end{array}\right] \\
& W_{4}=\left[\begin{array}{lllllllll}
0.1518 & 0.1472 & 0.1417 & 0.0847 & 0.1256 & 0.1103 & 0.0685 & 0.0725 & 0.0976
\end{array}\right]
\end{aligned}
$$

Table 4: The artificial decision statement $\left(\boldsymbol{B}_{\text {im }}\right)$

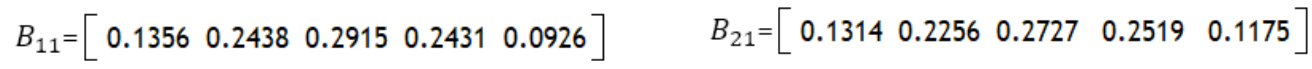

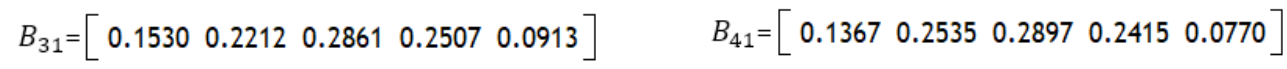

The rating scale weights $\left(W_{c}\right)$ of the statements about the county are:

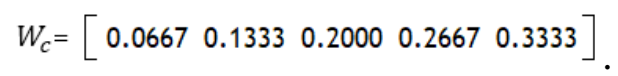

The $R=r_{i m}$ matrix of the artificial decision is:

$r_{i m}=\left[\begin{array}{llll}0.1955 & 0.1997 & 0.1942 & 0.1909\end{array}\right]^{T}$.

The $C R$ matrix obtained according to the decision criteria is:

$C R=\left[\begin{array}{lllll}0.1955 & 0.1955 & 0.1942 & 0.1909 & 0.8045\end{array}\right]^{T}$.

The $D_{j}$ matrix obtained from the inference system is:

$$
D_{j}=\left[\begin{array}{lllllllllll}
0.8045 & 0.9045 & 1.0000 & 1.0000 & 1.0000 & 1.0000 & 1.0000 & 1.0000 & 1.0000 & 1.0000 & 1.0000 \\
0.8045 & 0.8361 & 0.8939 & 0.9688 & 1.0000 & 1.0000 & 1.0000 & 1.0000 & 1.0000 & 1.0000 & 1.0000 \\
0.8058 & 0.8158 & 0.8458 & 0.8958 & 0.9658 & 1.0000 & 1.0000 & 1.0000 & 1.0000 & 1.0000 & 1.0000 \\
0.8091 & 0.8091 & 0.8091 & 0.8091 & 0.8091 & 0.8091 & 0.8091 & 0.8091 & 0.8091 & 0.8091 & 1.0000 \\
1.0000 & 1.0000 & 0.9955 & 0.8955 & 0.7955 & 0.6955 & 0.5955 & 0.4955 & 0.3955 & 0.2955 & 0.1955
\end{array}\right] .
$$

The fuzzy multicriteria decision matrix $(D)$ is:

$D=\tilde{E}_{1}=\left[\frac{0.4219}{0}+\frac{0.4991}{0.1}+\frac{0.6089}{0.2}+\frac{0.6288}{0.3}+\frac{0.6216}{0.4}+\frac{0.5627}{0.5}+\frac{0.4818}{0.6}+\frac{0.4009}{0.7}+\frac{0.3200}{0.8}+\frac{0.2391}{0.9}+\frac{0.1955}{1}\right]$.

The membership function of $D$ matrix for $u_{1}$ is shown in Figure 4.

According to $H_{l}\left(E_{m \alpha}\right)=\frac{1}{N_{\alpha}} \sum_{n=1}^{N_{\alpha}} Z_{n}(\alpha) ; E_{1 \alpha}, H_{l}\left(E_{1 \alpha}\right)$, and $\Delta$ a values are calculated in Table 5 . Then the point value of $\tilde{E}_{1}$ can be calculated as follows:

$$
\begin{aligned}
& S(1)=\frac{1}{\alpha_{\max }} \sum_{l=1}^{11} H_{l}\left(E_{1 \alpha}\right) \Delta \alpha_{l} \\
& =\frac{1}{0.6288}(0.50(0.1955)+0.45(0.0436)+0.40(0.0809)+0.35(0.0809)+0.30(0.0210) \\
& +0.35(0.0599)+0.30(0.0173)+0.35(0.0636)+0.30(0.0462)+0.35(0.0127) \\
& +0.30(0.0072)) \\
& =\frac{1}{0.6288}(0.2532)=0.4027
\end{aligned}
$$




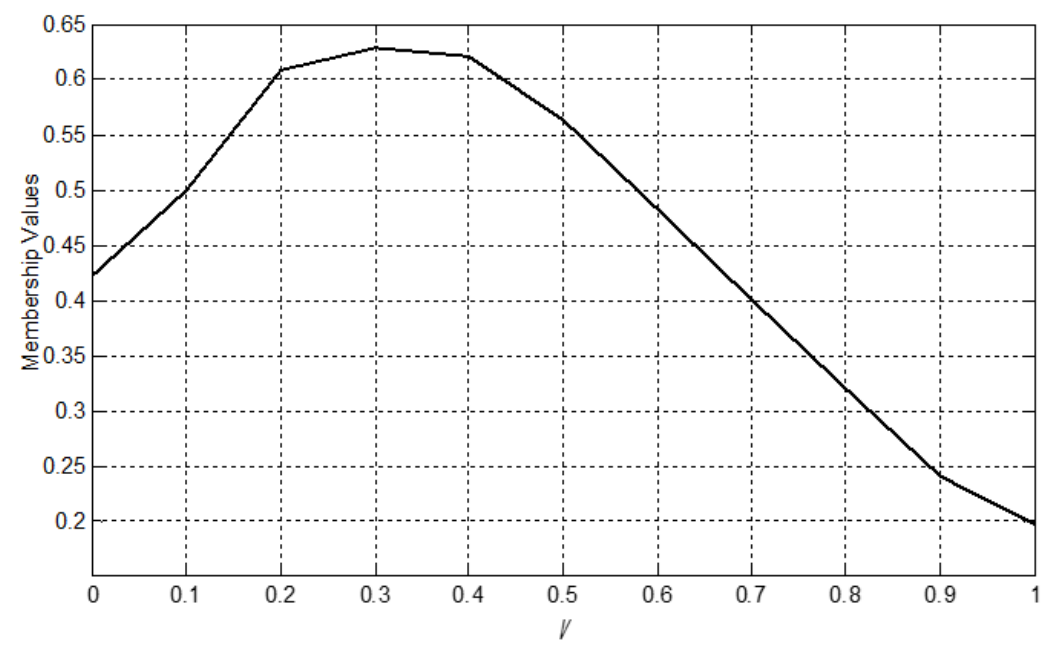

Figure 4: The membership function of local entrepreneurial culture, $u_{1}$.

Table 5: The a-level sets of local entrepreneurial culture, $\boldsymbol{u}_{1}$.

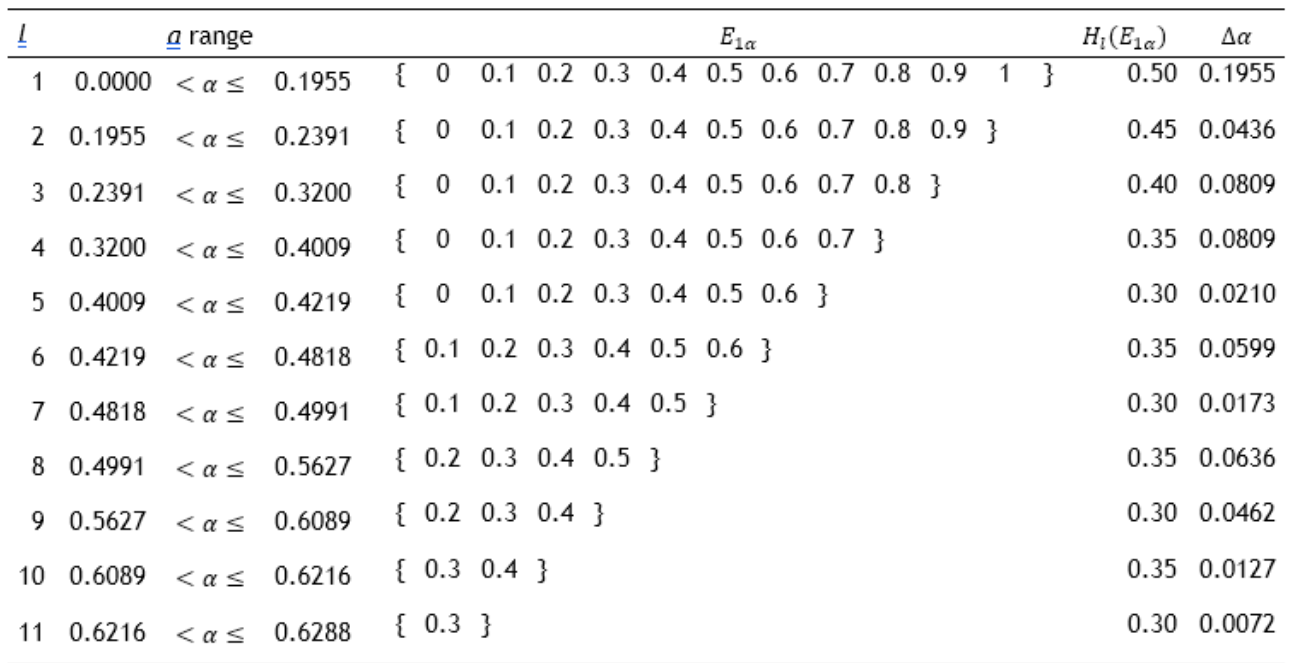

Thus, the value that measures the local entrepreneurship culture $\left(u_{1}\right)$ is obtained as 0.4027 . The local entrepreneurship culture of the entrepreneurs under consideration was under the middle level. This result supports the findings of international reports on entrepreneurship. According to the research/s carried out by the World Bank and the Global Entrepreneurship Development Institute, Kyrgyzstan ranked below the middle level. On the other hand, this index $(0.4027)$ only represents Bishkek, the capital of Kyrgyzstan, and may be the highest level in the country, as Bishkek is the main centre of attraction for businesses, investments, and human resources.

\section{CONCLUSION, AND FURTHER WORK}

Entrepreneurship is an important phenomenon in both developed and developing countries. Kyrgyzstan is a post-Soviet country located in Central Asia that declared its independence in 1991. Since gaining its independence, Kyrgyzstan has implemented reforms in order to develop a market economy. While Kyrgyzstan's economic transition and macroeconomic condition have been widely investigated, very little has been written about the country's development of entrepreneurship.

Recent literature has emphasised the significant relationship between culture and entrepreneurship. Lee et al. emphasised the role of national culture in stimulating entrepreneurial orientation [4]. Lalonde analysed the impact of culture on the process of starting a new venture and identified significant impacts [20]. Entrepreneurship culture is linked with the values shared by entrepreneurs, 
such as risk-taking, innovativeness, and pro-activeness. A planned economic system, in which social and economic life are completely regulated by the state, limits the ability of people to take risks and, therefore, their spirit of creativity. The evaluation of entrepreneurial culture is crucial for productive entrepreneurship and sustained private sector development. The empirical result of this paper identifies the position in Kyrgyzstan.

In this study, a fuzzy model was constructed and implemented to measure local entrepreneurial culture. This approach is a suitable way to accommodate the imprecise and qualitative factors inherent in attempting to measure local entrepreneurial culture in a community in a specific location. Besides contributing to the assessment of local entrepreneurial culture in the community development literature, this model can also be used to focus on general cultural attributes, rather than on the perception that residents hold about the entrepreneurial climate. This paper provides a framework for policy makers to assess entrepreneurial culture for community development, and thereby contributes to future entrepreneurship research. It also identifies key decision areas or practices for entrepreneurship, and assesses the role of local cultural characteristics in entrepreneurship. From this study, Local managers can deduce that a low cultural environment appears to be a significant barrier to doing business. These programmes that work to develop entrepreneurs must focus on assessing and trying to improve the local entrepreneurial culture.

The local entrepreneurship culture in Bishkek was estimated as 0.4027, which is below the middle level. This result supports the findings of international reports on entrepreneurship carried out by the World Bank and the Global Entrepreneurship Development Institute, where Kyrgyzstan ranked below the middle level. To conclude, the results of this study should be very helpful in suggesting potential avenues for policy-makers and for government officials to improve entrepreneurship in their countries. To promote entrepreneurship development, the government should engage in redirecting and integrating the emerging entrepreneurship into legal and productive sectors of the economy.

However, the paper has several limitations. First, the research was conducted in the capital city of the country. Bishkek is not only the administrative capital, but also the business and trade centre of the country. Representativeness may thus be a concern. In the future, additional studies may need to be conducted in other parts of the country. Furthermore, a non-probability sampling method was used, which would further reduce the representativeness of the sample.

In future studies, the paper can be used as a scale to test the conceptual model presented above, and also to test the measure for reliability and validate it for specialised cultures. Entrepreneurial cultures may, or may not, be stable over time. So, it can test whether these correlate with entrepreneurial activities by obtaining local panel data from the developed model for every year. Furthermore, a forecasting model can be constructed for estimating local entrepreneurial culture. This model can be useful for the long-term stability of underlying local cultural differences.

\section{REFERENCES}

[1] Beugelsdijk, S. 2007. Entrepreneurial culture, regional innovativeness and economic growth. Journal of Evolutionary Economics, 17, pp. 187-210.

[2] Osoba, B.J. 2009. Culture and entrepreneurial activity in the United States: A quantitative analysis. Innovation: The European Journal of Social Science Research, 22(3), pp. 341-370.

[3] Lasch, F., Dana, L.P. \& Mueller, J. 2009. Diversity in Central Asia: Culture, transition \& entrepreneurship. Journal of Asia Entrepreneurship and Sustainability, 5(1), pp. 44-56.

[4] Lee, S.M., Lim, S. \& Pathak, R.D. 2011. Culture and entrepreneurial orientation: A multi-country study. International Entrepreneurship Management Journal, 7(1), pp. 1-15.

[5] Marti, I., Courpasson, D. \& Barbosa, S.D. 2013. 'Living in the fishbowl': Generating an entrepreneurial culture in a local community in Argentina. Journal of Business Venturing, 28(1), pp. 10-29.

[6] Huggins, R. \& Thompson, P. 2014. Culture, entrepreneurship and uneven development: A spatial analysis. Entrepreneurship \& Regional Development, 26(9-10), pp. 726-752.

[7] Chaşovschi, C., Bordeianu, O. \& Clipa, D. 2014. Entrepreneurial culture in transition economies: The case of Romania and Republic of Moldova. Procedia Economics and Finance, 15, pp. 1507-1514.

[8] Brownson, Ch.D. 2015. Entrepreneurship awareness and entrepreneurial culture in Nigeria. Entrepreneurship and Innovation Management Journal, 3(3), pp. 118-128.

National Statistical Committee of the Kyrgyz Republic. [accessed 15 January 2017] http://stat.kg/media/publicationarchive/319b4776-7250-4fbf-be72-3f6c2482a823.pdf,

[9] The World Bank. Doing Business. http://www.doingbusiness.org/reports/global-reports/doing-business2016, accessed 18.01.2017. 
[10] Breazeale, N., Fortunato, M.W.-P., Allen, J.E., Hustedde, R.J. \& Pushkarskaya, H. 2015. Constructing a multi-dimensional measure of local entrepreneurial culture. Community Development, 46(5), pp. 516540.

[11] Dimitratos, P., Voudouris, I., Plakoyiannaki, E. \& Nakos, G. 2012. International entrepreneurial culture: Toward a comprehensive opportunity-based operationalization of international entrepreneurship. International Business Review, 21, pp. 708-721.

[12] Seaman, C., Bent, R. \& Unis, A. 2015. Family entrepreneurship culture, entrepreneurial intent, futures and foresight in Scottish Pakistani Communities. Futures, 75, pp. 83-91.

[13] GEM: Global Entrepreneurship Monitor Consortium. 2016/17 Global report. http://www.gemconsortium.org/report, accessed 15.01.2017.

[14] GEINDEX: The Global Entrepreneurship and Development Institute. 2017 Global Entrepreneurship Index. https: //thegedi.org/2017-global-entrepreneurship-index/, accessed 15.01.2017.

[15] WBGES: The World Bank, World Bank Group Entrepreneurship Survey. http://www.doingbusiness.org/data/exploretopics/entrepreneurship, accessed 15.01.2017

[16] Marcotte, C. 2013. Measuring entrepreneurship at the country level: A review and research agenda. Entrepreneurship \& Regional Development, 25(3-4), pp. 174-194.

[17] Mogollón, R.H. \& Rubio, P.P. 2010. An approach to entrepreneurial culture and education in secondary school. International Journal of Business Environment, 3(1), pp. 120-134.

[18] Mansor, M. \& Othman, N. 2011. CoBLAS: Inculcating entrepreneurial culture among higher education institutions' students. International Journal of Social Science and Humanity, 1(1), pp. 86-91.

[19] Lalonde, J.F. 2013. Cultural determinants of Arab entrepreneurship: An ethnographic perspective. Journal of Enterprising Communities: People and Places in the Global Economy, 7(3), pp. 213-232.

[20] Choo, S. 2005. Developing an entrepreneurial culture in Singapore: Dream or reality. Asian Affairs, 36(3), pp. 361-373.

[21] Haris, N.A. \& Rahman, F.A. 2017. A study on application of fuzzy methods in entrepreneurship domain. International Journal of Advanced and Applied Sciences, 4(12), pp. 206-211.

[22] Mavi, R.K. 2014. Indicators of entrepreneurial university: Fuzzy AHP and fuzzy TOPSIS approach. Journal of the Knowledge Economy, 5(2), pp. 370-387.

[23] Han, J.-Y., Yang, Y.-B. \& Zhao, Y.-H. 2012. Evaluation of entrepreneurial environment based on fuzzy comprehensive evaluation method. In: 2012 International Conference on Machine Learning and Cybernetics, ICMLC, 1, pp. 305-309.

[24] Dehkordi, A.M., Sasani A., Fathi M.R. \& Khanmohammadi, E. 2012. Investigating the effect of emotional intelligence and personality traits on entrepreneurial intention using the fuzzy DEMATEL method. International Journal of Business and Social Science, 3(13), pp. 286-296.

[25] Arafeh, L. 2016. An entrepreneurial key competencies' model. Journal of Innovation and Entrepreneurship, 5, pp. 1-26.

[26] Khefacha, I. \& Belkacem, L. 2015. Modeling entrepreneurial decision-making process using concepts from fuzzy set theory. Journal of Global Entrepreneurship Research, 5(1), pp. 13-34.

[27] Sheela, P. \& Murthy, M. 2015. The use of fuzzy analytical hierarchy process (FAHP) model for the primary screening of business opportunity in the process of entrepreneurial activity. International Journal of Marketing, Financial Services and Management Research, 4(5), pp. 1-14.

[28] Ferreira, P. \& Dionısio, A. 2016. Entrepreneurship rates: The fuzzy-set approach. Eastern European Business and Economics Journal, 2(2), pp. 111-128.

[29] Alroaia, Y.V., Hemati, M. \& Javadinia, M. 2012. A new approach to develop entrepreneurship of the industry using fuzzy DEMATEL. Management Science Letters, 2(4), pp. 1279-1288.

[30] Munoz, P. \& Kibler, E. 2016. Institutional complexity and social entrepreneurship: A fuzzy-set approach. Journal of Business Research, 69(4), pp. 1314-1318.

[31] Rezaei, J., Ortt, R. \& Scholten, V. 2013. An improved fuzzy preference programming to evaluate entrepreneurship orientation. Applied Soft Computing, 13(5), pp. 2749-2758.

[32] Ross, T.J. 2010. Fuzzy logic with engineering applications. New York: McGraw-Hill.

[33] Cronbach, L.J. 1951. Coefficient alpha and the internal structure of tests. Psychometrika, 16, pp. 297334.

[34] George, D. \& Mallery, P. 2003. SPSS for Windows step by step: A simple guide and reference. 11.0 update (4 $4^{\text {th }}$ ed.). Boston: Allyn \& Bacon.

[35] Göleç, A. \& Taşkın, H. 2007. Novel methodologies and a comparative study for manufacturing systems performance evaluations. Information Sciences, 177(23), pp. 5253-5274.

[36] Stillwell, W.G., Seaver, D.A. \& Edwards, W. 1981. A comparison of weight approximation techniques in multiattribute utility decision making. Organizational Behavior and Human Performance, 28(1), pp. 62-77.

[37] Yager, R.R. 1982. Multicriteria decisions with soft information: An application of fuzzy set and possibility theory. Fuzzy Mathematics, 2(2), pp. 21-28. 